\title{
LAS ANAMORFOSIS DE POINCARÉ: UNA MIRADA OBLICUA A LAS MATEMÁTICAS, LA PINTURA Y LA POESÍA
}

\author{
Francisco GONZÁLEZ FERNÁNDEZ \\ Universidad de Oviedo \\ frangon@uniovi.es
}

S obre un fondo tapizado con innumerables rayas verdosas, se impone a la mirada la presencia de Henri Poincaré. Exceptuando su barba poblada, que ya empieza a clarear, el eminente matemático apenas ha cambiado desde su juventud; sigue vistiendo un traje austero al que una pajarita apenas visible aporta el necesario toque de distinción. Inmóvil en su pose, detrás de sus inseparables quevedos permanece ajeno a lo que le rodea, como si contemplara fuera de plano algún punto infinito. El retrato no puede ser más anodino y sin embargo, tal vez debido a su atmósfera olivácea, resulta extraño y hasta inquietante. Y de repente se confirman las sospechas, la imagen parece desencajarse y la figura de Poincaré ladearse, estirarse como si fuera de chicle, alargándose en diagonal su rostro hasta perder todo su aspecto rollizo. Pero ésta no es más que la primera de una larga serie de transformaciones a las que la imagen se verá sometida. Ahora, en el siguiente paso, aumenta la deformación un grado más al plegarse, desdoblarse y fragmentarse la figura del matemático. Y poco a poco, al surgir cada nueva imagen, Poincaré se desdibuja a fuerza de estirarse y dividirse hasta no componer más que una multitud de líneas diagonales cada vez más finas y difusas que terminan desintegrándose en una niebla puntillista. El padre del caos moderno ha sido engullido por la pantalla.

Así quiso en 1986 ilu strar el físico James Crutchfield el modo en que surgía el caos (en su sentido matemático actual) de una operación geométrica de estiramiento y plegamiento por medio de la iteración de una ecuación no lineal. En un artículo de la revista Scientific American, él y sus colaboradores reprodujeron el mosaico de cambios al que habían sometido el retrato de Poincaré mediante su manipulación por ordenador logrando que la imagen pareciera estar pintada sobre una lámina de goma. Este proceso se inspiraba en la conocida «transformación del panadero», un modelo dinámico que toma su nombre del ejemplo de un panadero al que se le encomendara extender con su rodillo una masa de forma cuadrada, replegando luego los trozos sobrantes en los espacios que quedaran vacíos en el marco inicial para a continuación repetir la misma acción una y otra vez. En semejante proceso los puntos contiguos de la superficie no tardan en alejarse unos de otros 
distribuyéndose de manera homogénea sobre la totalidad del espacio y por ello, en el caso presente, pronto los rasgos de la figura retratada se vuelven irreconocibles. Sin embargo, el matemático no llega a desaparecer del todo, sino que permanece por así decirlo escondido en el cuadro. En efecto, al seguir realizando la operación de estiramiento y plegamiento el tiempo suficiente puede observarse que en determinado momento los puntos se acercan a su posición inicial provocando la breve aparición de la imagen original. La figura de Poincaré reaparece primero de forma difusa y múltiple, como vista a través de un caleidoscopio (paneles 47-48) para finalmente surgir de nuevo prácticamente tal como era en el punto de partida (paneles 239-241). Mediante una extraña combinación de azar y determinismo el matemático francés sale repentinamente de entre la niebla para atraer las miradas sobre él. El errático devenir de su imagen cobra la forma de un atractor extraño.

\section{En busca de una imagen caótica del universo}

Henri Poincaré se dio a conocer como matemático en 1889 al ganar el premio del concurso propuesto por el rey de Noruega con una memoria Sobre el problema de los tres cuerpos y las ecuaciones dinámicas. Lejos de ser un asunto menor, este problema constituía el gran desafío de la Mecánica Celeste. Consistía esencialmente en calcular la trayectoria de tres o más cuerpos (como el Sol, la Luna y la Tierra) moviéndose en el espacio bajo la mutua atracción de la gravedad. Newton ya había resuelto geométricamente el problema de los dos cuerpos (por ejemplo, la Tierra y el Sol) demostrando que cada cuerpo recorre una órbita elíptica según las leyes de Kepler. Pero esto no se correspondía a la realidad del sistema solar que es mucho más compleja al intervenir un mayor número de cuerpos celestes en mutua interacción. Cabía preguntarse qué efecto tendrían todas estas fuerzas sobre los planetas y si estos se desplazarían necesariamente siguiendo las órbitas elípticas como indicaba la ley de Kepler o por el contrario algún cuerpo podría alejarse indefinidamente. Poincaré, mediante nuevos métodos, cualitativos en lugar de cuantitativos, es decir tratando de hallar una imagen que captara la fisonomía de la ecuación y del sistema físico que representaba en vez de ir sumando los cambios infinitesimales, como se hacía hasta la fecha, descubrió que no era posible encontrar una solución como lo había hecho Newton para el problema de los dos cuerpos. En el seno mismo de la Mecánica Celeste, paradigma hasta entonces del determinismo, Poincaré había hallado fenómenos caóticos al descubrir que en determinados casos una pequeña variación en las condiciones iniciales engendra tales diferencias en los fenómenos finales que no es posible prever la evolución del sistema. A pesar de ser habitualmente partidario de visualizar los problemas científicos, el matemático francés llegó en esta ocasión a decir que las intersecciones de las curvas estables e inestables de un sistema de tres cuerpos formaban una malla tan infinitamente apretada, de tanta complejidad que él renunciaba incluso a dibujar su figura. De haberlo intentado esta «inextricable maraña de curvas» se habría parecido a un lienzo de Jackson Pollock...

Así pues, Poincaré había modificado radicalmente, a su pesar, la imagen del universo en el que reinaba ahora el «caos determinista». Derribada la vieja concepción del mundo, sostenía a este respecto 
Ivar Ekeland, se hacía necesario encontrar una nueva imagen que diera cuenta de la realidad: «La imagen anterior era la órbita kepleriana, plana, elíptica y periódica, en todo caso esencialmente previsible y calculable: la Tierra gira alrededor del Sol, hoy, mañana y por toda la eternidad. Esta imagen ha resultado ser engañosa, la órbita kepleriana se disolvió en un halo y nadie sabe si la Tierra girará siempre alrededor del Sol. ¿Qué imagen nueva proponemos?» ${ }^{1}$. Después de descartar el juego de dados por inadecuado, Ekeland concluía que ya existía una imagen perfectamente ajustada para simbolizar este nuevo mundo y que había surgido justamente del trabajo de varias generaciones de matemáticos que habían investigado los sistemas dinámicos siguiendo los pasos de Poincaré. Esta imagen no es otra que «la transformación del panadero» en la que se había basado Crutchfield para componer precisamente el mosaico de Poincaré.

Obviamente, al elegir la imagen de Henri Poincaré como motivo de la operación de estiramiento y plegamiento, Crutchfield había querido rendir un sincero y a la vez divertido homenaje al fundador de la teoría de los sistemas dinámicos expresando además su deuda con el fenómeno conocido en mecánica estadística como «recurrencia de Poincaré» cuyo teorema había demostrado el matemático francés en el marco del problema de los tres cuerpos. De hecho, el propio Crutchfield matizaba en su artículo que la transformación mostrada tenía un carácter especial puesto que en este caso la «recurrencia de Poincaré» sucedía «con mucha más frecuencia que habitualmente», pues «en una típica transformación la recurrencia es sumamente poco común, ocurriendo quizás una sola vez en la vida del universo» ${ }^{2}$. Con ello subrayaba que la sucesión de cambios ofrecida al público no era nada más (y nada menos) que una imagen metafórica del teorema de Poincaré, una ilustración en la que el cuadro inicial realizado con pincel había sido retocado posteriormente procesando cada píxel de la imagen digitalizada. En este sentido el mosaico de Poincaré podría ser considerado como una prefiguración de esas obras de arte contemporáneo conocidas como «objetos sci-art» generadas a partir de imágenes científicas $^{3}$. Contemplada desde esta perspectiva, la deformación que sufre la figura de Poincaré vendría a ser una variante moderna de las anamorfosis que tan de moda estuvieron durante el siglo XVII entre los artistas y geómetras. Y del mismo modo, como tendremos ocasión de ver, que las anamorfosis fueron en aquella época la expresión artística del universo kepleriano de órbitas elípticas, el mosaico de Poincaré aparece como una anamorfosis moderna acorde con el universo contemporáneo regido por el caos determinista.

\footnotetext{
${ }^{1}$ Ivar Ekeland, El cálculo, lo imprevisto. Las figuras del tiempo de Kepler a Thom. México, Fondo de Cultura Económica, 1988, p. 78.

2 James Crutchfield, J. Doyne Farmer, Norman H. Packard \& Robert S. Shaw, «Chaos», Scientific American, 254/12, (diciembre 1986), p. 46.

${ }^{3}$ Véase Ailin María Reising \& Raúl Oscar Barrachina, «La producción de "objetos sci-art" a partir de visualizaciones científicas contemporáneas», en A. Passos Videira \& A. Torrano, eds., La representación en la ciencia y el arte. Selección de trabajos del III Simposio Internacional. Córdoba, Universidad Nacional de Córdoba, 2011.
} 
Las anamorfosis de Poincaré: una mirada oblicua a las matemáticas, la pintura y la poesía

\section{La anamorfosis como figuración epistemológica}

La anamorfosis, término que procede del griego ana (regreso hacia) y morphé (forma), es un subterfugio óptico que implica una deformación para poder regresar a su forma original. Como indica Baltrusaitis en su obra clásica, la anamorfosis es «una dilatación, una proyección de las formas fuera de sí mismas, conducidas de modo que se enderecen en un punto de vista determinado: una destrucción para un restablecimiento, una evasión pero que implica un regreso» ${ }^{4}$. Por ello, al deformarse para luego recobrar brevemente su aspecto inicial, la figura de Poincaré se manifiesta como un nuevo tipo de anamorfosis (digital) en cuyo juego, tal vez sin saberlo, Crutchfield ha expresado de forma emblemática un fenómeno que constituye la piedra angular del pensamiento del matemático francés y una perfecta metáfora del papel que desempeñan las artes visuales en su obra matemática. Pero para poder apreciar esta cuestión con cierta profundidad es preciso desviar previamente la mirada de la figura de Poincaré y detenerse a examinar la historia y la naturaleza de las anamorfosis.

Sin duda la imagen anamórfica más popular de la historia de la pintura se encuentra en Los embajadores (1533) de Holbein. En un espacio cerrado, construido con extremo rigor, dos personalidades se presentan en toda su grandeza, retratadas a tamaño natural, con tal fidelidad y sensación de relieve que a primera vista uno no puede dejar de preguntarse si se trata verdaderamente de un cuadro de dos dimensiones. Vestidos de gala, mirando frontal y fijamente al espectador, Jean de Dinteville, señor de Polisy, y su amigo Georges de Selve, obispo de Lavaur, posan a un lado y otro del mueble en el que se apoyan y que está repleto de instrumentos artísticos y científicos: en el estante superior aquellos objetos propios de las ciencias del cielo (globo celeste, clinómetro, etc.) y en el inferior aquellos propios de las ciencias de la tierra (globo terrestre, laúd, libros de aritmética y música, compás, etc.). Toda una representación del «Quadrivium», las artes relacionadas con las matemáticas, toda una exhibición de emblemas destacando sobre una cortina olivácea cuyos pliegues irregulares sugieren que algo permanece oculto entre bambalinas.

Retrato doble, lleno de dobleces y duplicidades, de miradas desdobladas. Retrato manierista y alegórico que descansa sobre el «Trivium», sobre las artes del lenguaje, y cuyo doble juego de perspectivas expresa ya con cierta melancolía la unión humanista de las Artes y de las Ciencias. Porque en primer plano, a los pies de los embajadores, se impone a la mirada del espectador una cosa hueca de forma alargada, de grandes dimensiones y de naturaleza ósea que parece estar flotando a ras del suelo. El objeto está ahí como un signo de interrogación, como una signatura, como una anomalía al pie de un cuadro de gran realismo. $\mathrm{Y}$ al igual que sucede en todo buen enigma solo cobra sentido cuando es abordado de forma figurada. Höhle bein: hueso hueco, en alemán. La cosa extraña como firma secreta del autor. Y también como signo de una segunda figuración, más profunda y trascendente, pues una vez abandonada la visión perpendicular a la que nos constriñen los embajadores con sus miradas y adoptando una posición y/o una mirada oblicua, aparece de repente, como por arte de magia, una calavera en toda su verdad. Desviación de la mirada, paso de una perspectiva a otra que restituye la imagen original que había sido deformada previamente por anamorfosis: una calavera que parece,

\footnotetext{
${ }^{4}$ Jurgis Baltrusaitis, Les perspectives dépravées. Tome 2- Anamorphoses. Paris, Flammarion, 2008, p. 7.
} 
en palabras de Rudolf Arnheim, haber sido «pintada sobre una lámina de goma y luego estirada hasta hacerla irreconocible» ${ }^{5}$. El hueso hueco de Holbein surge así en tanto que distorsión topológica, como si en la sombra que proyecta sobre el mosaico geométrico del suelo pudiera ya adivinarse la silueta de Henri Poincaré.

Aunque en la actualidad las anamorfosis no son más que simples curiosidades que explota con éxito la publicidad y que pueden reconocerse hasta en las señales de tráfico pintadas en el pavimento, en su origen constituyeron un efecto de perspectiva que fascinó por igual a artistas y a matemáticos. Como ha puesto de manifiesto Baltrusaitis, las imágenes deformadas y restablecidas hicieron su aparición en el siglo XVI primero en Italia, seguramente de la mano de Leonardo da Vinci, propagándose rápidamente por los países del Norte de Europa con grabadores como Erhard Schön, pero el término 'anamorfosis' no surgió hasta bien entrado el siglo siguiente, justamente cuando la perspectiva alterada penetró en el campo de la razón y se publicaron abundantes compilaciones teóricas y prácticas donde se revelaban geométricamente los secretos de su elaboración hasta entonces celosamente guardados por los artistas.

En efecto, a lo largo del siglo XVII, periodo en que las anamorfosis alcanzan su mayor popularidad - especialmente aquellas que operan mediante un espejo cilíndrico-, proliferan los tratados de perspectiva donde las formas distorsionadas dejan de ser abordadas por medios empíricos para en su lugar ser estudiada y enseñada su composición como una ciencia exacta. De entre los numerosos «perspectores» de aquella época destacan el matemático François Niceron, el arquitecto Salomon de Caus y Jean Dubreuil, cuyas perspectivas curiosas son tratados científicos basados en la geometría de los rayos visuales y en cálculos precisos. En esta renovación de los estudios de las combinaciones ópticas acometida entonces sobre todo en Francia desempeña un papel determinante el convento de la orden de los Mínimos de París, un importante foco de estudios científicos, que contaba entre sus miembros con los matemáticos Niceron, Maignan y Mersenne, y tan estrechamente vinculado a Descartes y su interés por la óptica y la geometría que según Baltrusaitis constituye un auténtico centro cartesiano: «Por una curiosa coincidencia, todos aquellos que se ocuparon de las perspectivas insólitas se encuentran más o menos relacionados con el autor del Discurso del método. Aunque dispersos, pertenecen al mismo círculo, con el convento parisino como centro de contacto, y trabajan en la misma dirección» ${ }^{6}$. No es extraño, pues, que se conserve una anamorfosis cilíndrica de Descartes que parece haber sido realizada a partir del famoso retrato que hizo Frans Hals del matemático y filósofo. Y es que en torno a la anamorfosis, imagen deformada como si se acercara un trozo de cera al fuego, confluyen las más diversas reflexiones sobre la percepción y la verdad.

Por su propia naturaleza, la anamorfosis era una de las figuras más idóneas para expresar el cambio epistemológico que había empezado a producirse durante la disolución del Renacimiento. La calavera anamórfica de Holbein no simbolizaba únicamente la vanidad del conocimiento científico frente a la evidencia de la muerte, también desvelaba la revolución epistemológica de la que el pintor

\footnotetext{
${ }^{5}$ Rudolf Arnheim, Arte y percepción visual. Madrid, Alianza Editorial, 1979, p. 289.

${ }^{6}$ Jurgis Baltrusaitis, op. cit., p. 87.
} 
y sus contemporáneos estaban siendo testigos. El viaje trasatlántico que Colón había emprendido unos cuarenta años antes, con la ayuda de esos mismos instrumentos que custodian los embajadores retratados, modificó drásticamente la visión europea del mundo y cambió para siempre la imagen de un planeta que parecía ser objeto de una formidable anamorfosis. Pronto el giro copernicano hizo desaparecer la sensación de estabilidad y de orden inmutable para poner de manifiesto la existencia de un universo desconcertante y descentralizado. La teoría copernicana supuso, en palabras de Arnold Hauser, «el primer paso para el conocimiento del carácter perspectivo del pensar, y con ello, de la relatividad de la verdad» ${ }^{7}$. Durante el periodo manierista, cuando la Tierra abandonaba irrevocablemente su posición central en el Universo para ubicarse en la órbita del Sol, la perspectiva dislocada se puso de moda y se convirtió en una suerte de emblema de un mundo que bajo el signo de la ciencia estaba en plena transformación. Y como la descomposición y la recomposición de las formas respondían al rigor de las leyes ópticas, los caprichos del arte y de la imaginación encontraron en la anamorfosis el aval de la ciencia perspectiva convirtiéndose en una imagen de la que no dudaron en apropiarse los poetas y dramaturgos.

Shakespeare, por ejemplo, recurriría en Ricardo II y en Bien está lo que bien acaba a comparaciones anamórficas para expresar de manera gráfica las alteraciones en el juicio producidas por sentimientos como el dolor o el desprecio. Pero, más que como símil literario, la anamorfosis, empleada ya de forma recurrente por los artistas del siglo XVI con fines simbólicos en cuadros religiosos y enigmáticos, se manifestó como una equivalencia visual de la alegoría sobre la que descansaban numerosas ficciones poéticas de entonces. Fue precisamente este estrecho vínculo con el alegorismo lo que le valió a la anamorfosis su más firme condena. Y esta crítica de la perspectiva descentrada no fue obra de ningún poeta sino del mismísimo Galileo, sin duda el científico que paradójicamente había contribuido de forma más decisiva a defender el nuevo modelo copernicano del Universo.

Hijo de un importante músico de la época, Galileo creció en un entorno humanista que le proporcionó excelentes conocimientos literarios, artísticos y musicales. El físico y astrónomo que concebía el universo como un libro escrito en lengua matemática fue considerado gracias a sus Diálogos y Discursos como uno de los más grandes prosistas de la lengua italiana por escritores como Leopardi o Italo Calvino. Gran aficionado a la poesía, Galileo profesaba una honda admiración por la Comedia de Dante a la que dedicó dos lecciones en las que trataba de medir la arquitectura del Infierno $^{8}$, pero sentía aun mayor predilección por la obra de Ariosto, a quien debía, según él mismo confesó, todo lo que su propio estilo tenía de claridad y evidencia. Además, al padre de la mecánica moderna le gustaba implicarse en los frecuentes debates literarios y artísticos de su tiempo, como la polémica acerca de la preeminencia de la pintura o de la escultura. Especial interés despertó en él la querella surgida a finales del siglo XVI entre los partidarios del Orlando furioso de Ariosto y los

\footnotetext{
${ }^{7}$ Arnold Hauser, El Manierismo. La crisis del Renacimiento y los orígenes del mundo moderno. Madrid, Guadarrama, 1965 , p. 72.

${ }^{8}$ Galileo Galilei, Dos lecciones infernales. Madrid, La Compañía de los Libros, 2012.
} 
admiradores de la Jerusalén liberada de Tasso. Galileo no tardó en entrar en esta contienda verbal publicando sus Consideraciones a Tasso en las que, claro está, tomaba partido por la obra y el estilo de Ariosto a la vez que criticaba hasta la caricatura la poesía de Tasso, cuyos versos e imágenes eran a su juicio absurdamente oscuros, recargados y retorcidos. En nombre de la claridad y de la exactitud, y en lógica consonancia con el espíritu de su obra científica, Galileo defendía una escritura coherente y rigurosa, abiertamente contraria a la estética manierista. Por ello, se inclinaba por el uso de comparaciones sencillas y evidentes en detrimento del estilo artificial y del abuso de extrañas metáforas que corrían el riesgo de confundir al lector. En este sentido nada estaba más alejado de su ideal estético que las alegorías, a las que comparaba con las anamorfosis:

Señor Tasso quiero que sepa que las fábulas y las ficciones poéticas tienen que servir al sentido alegórico de manera que en estas no aparezca una mínima sombra de constricción, de otro modo se caerá en lo dificultoso, lo forzado, lo desgarrado; lo mismo sucede con una de esas pinturas que, al mirarlas en escorzo desde un punto determinado nos muestran una figura humana, pero que están diseñadas con tales reglas de perspectiva, que vistas de frente, y como natural y comúnmente se ven las demás pinturas, no representan nada más que una confusa y desordenada mezcla de líneas y de colores, en las cuales con mucha aplicación podríamos recomponer imágenes de ríos, de caminos sinuosos, de playas desiertas, de nubes o de extrañas quimeras. Y si esta clase de pinturas, que principalmente están hechas para ser miradas en escorzo, y que sería inconveniente contemplar de frente, al no representar otra cosa que una mezcolanza de patas de grullas, de picos de cigüeñas y otras figuras desarregladas, más digno aun de reproche resulta en la ficción poética que la fábula corriente descubierta y contemplada sencillamente al principio tenga que acomodarse a la alegoría oblicuamente vista y así esté atestada subrepticia y extravagantemente de quimeras e imaginaciones fantásticas y superfluas. ${ }^{9}$

Alegoría y anamorfosis son para Galileo técnicas artísticas de doble sentido que entrañan confusión y desorden. A simple vista podría interpretarse sencillamente esta analogía entre una forma poética enigmática y una forma plástica extravagante como una manera más de denigrar la estética de Tasso, pero hace años, en un artículo que hizo época en la historia de la epistemocrítica, Erwin Panofsky puso de manifiesto que en estas líneas traslucía una idea crucial para entender no solo la actitud estética de Galileo sino también su pensamiento científico. En opinión de este prestigioso crítico de arte sería erróneo explicar los gustos estéticos del físico florentino simplemente como el resultado de sus disposiciones científicas, como si fuesen tan solo fruto de su mentalidad rigurosa y racional. En «Galileo as a Critic of the Arts», Panofsky se preguntaba con acierto si no podría mirarse la cuestión desde otra perspectiva, si acaso las convicciones científicas de Galileo no estarían asimismo influidas por su actitud estética, o para ser más precisos, si como hombre de arte y como hombre de ciencia Galileo no obedecería al mismo tipo de controles.

En efecto, al abordar el sorprendente silencio que el matemático italiano siempre había guardado sobre las leyes planetarias de Kepler, a pesar de conocerlas sobradamente, Panofsky llegaba a la conclusión de que si Galileo no había integrado en su teoría el modelo elíptico de las órbitas del gran astrónomo alemán era debido a la fascinación que sentía por la forma circular, asociada todavía en su época a la perfección y más acorde con la estética renacentista (regida por una estructura de círculos concéntricos con el hombre en el centro) que manierista: «Allí donde nosotros consideraríamos al

\footnotetext{
${ }^{9}$ Galileo Galilei, Considerazioni al Tasso. Roma, Stamperia Pagliarini, 1793, p. 77. La traducción del italiano es del autor.
} 
círculo como un caso particular de la elipse, Galileo no podía concebir la elipse más que como un círculo deformado» ${ }^{10}$. Y la misma obsesión circular que le había empujado a eliminar la elipse de su pensamiento científico de forma prácticamente automática era responsable del rechazo que despertaba en él la anamorfosis en el mundo del arte. Alexandre Koyré resumía precisamente el argu mento de Panofsky diciendo que «Galileo sentía por la elipse la misma invencible aversión que experimentaba por la anamorfosis; y que la astronomía de Kepler era para él una astronomía manierista» ${ }^{11}$. Esta asociación de ideas científicas y estéticas debió de surgir con naturalidad en la mente de Galileo pues, al fin y al cabo, nada resultaba más sencillo que concebir una elipse como la anamorfosis de un círculo. A este respecto, Javier Navarro de Zuvillaga explicaba, en ese prodigioso gabinete de curiosidades geométricas que son sus Imágenes de la perspectiva, que «la elipse es la proyección de una circunferencia; es por tanto su anamorfosis además de su sombra», y añadía que «teniendo en cuenta que la circunferencia y la elipse son formas simbólicas del Renacimiento y del Barroco, respectivamente, se podría decir que la imagen del mundo barroco es una anamorfosis de la del mundo clásico» ${ }^{12}$.

Así pues, si bien Galileo puede ser considerado con justicia como el padre de la ciencia moderna al haber abandonado toda concepción mística de la naturaleza, por contrapartida nunca dejó de estar sometido a las prevenciones del clasicismo. Le tocó vivir entre la edad de oro del Renacimiento y la edad de oro del Barroco, durante ese periodo de transición y cambio, anamórfico, conocido como Manierismo, contra cuyas formas artísticas «degeneradas» reaccionó con tanta pasión. En su visión de la realidad la circunferencia y la elipse pertenecían a ámbitos totalmente diferenciados. Fue al final de sus días, durante el periodo de esplendor de los tratados de perspectiva (entre 1630 y 1680), en la época precisamente en que las anamorfosis alcanzaron su mayor auge, cuando un geómetra francés, Girard Desargues, realizó otro giro revolucionario al concebir el círculo, la elipse, la parábola y la hipérbole como las transformaciones proyectivas de una misma figura, y a la vez que unificaba las secciones cónicas inventó una nueva geometría.

\section{Geometría proyectiva y mirada anamórfica}

Aunque caído en el olvido durante casi dos siglos, Desargues fue probablemente el perspector y geómetra más importante de su generación. Según él mismo confesó, la observación de que gran parte de las artes se basa en la geometría le impulsó a buscar un método que abarcara todos los casos que se le podían presentar al artista $^{13}$. La geometría de posición basada en técnicas proyectivas que se propuso

\footnotetext{
${ }^{10}$ Erwin Panofsky, «Galileo as a Critic of the Arts: Aesthetic and Scientific Thought», Isis, 47/1 (marzo 1956), p. 12.

11 Alexandre Koyré, «Actitud estética y pensamiento científico», en Estudios de historia del pensamiento científico. Madrid, SigloVeintiuno de España Editores, 1990, p. 269.

12 Javier Navarro de Zuvillaga, Imágenes de la perspectiva. Madrid, Siruela, p. 392 Sobre un planteamiento similar, retomando expresamente las ideas de Panofsky, el novelista Severo Sarduy trató años atrás en su ensayo Barroco (Buenos Aires, Sudamericana, 1974) de elucidar el campo simbólico del Barroco examinando de cerca la oposición entre el círculo de Galileo y la elipse de Kepler, entre la perspectiva central y la anamorfosis.

${ }^{13}$ Véase Martin Kemp, La ciencia del arte. La óptica en el arte occidental de Brunelleschi a Seurat. Madrid, Akal, 2000, pp. 132-133.
} 
construir surge por lo tanto de las investigaciones perpectivistas que a lo largo de todo el Renacimiento vinieron haciendo los artistas. Al realizar la síntesis de esta ciencia perspectiva y de la teoría de las cónicas Desargues formalizó lo que los pintores habían intuido en sus estudios. El hecho, por ejemplo, de que una aureola pintada sobre la cabeza de un santo diera la impresión de ser circular cuando en realidad no era más que una elipse ya sugería que debían de existir unas propiedades geométricas comunes a las distintas secciones de una misma proyeccion y a las secciones de dos proyecciones distintas de una escena determinada. Esta cuestión intrigaba a más de un matemático pero fue Girard Desargues quien le dio respuesta hallando estas propiedades comunes.

Es interesante a este respecto destacar que el origen de la geometría proyectiva cuyas bases sentó Desargues está ligado a las anamorfosis que proliferaron por esa misma época. Como recuerda Gérard Chazal, en la geometría proyectiva lo que importa no son las medidas sino esencialmente las formas y la posibilidad de metamorfosis y anamorfosis que éstas poseen: «Aquí una vez más la sombra del arte se extiende un poco más sobre la teorización geométrica y no pueden dejar de evocarse las numerosas anamorfosis pintadas en la misma época en que Desargues funda la geometría proyectiva» ${ }^{14}$. Para algunos, como es el caso de Denis Favennec, el modelo de las anamorfosis habría influido en la invención de la geometría proyectiva e inspirado a los matemáticos la noción de transformación e invariante. Para otros, como Fernando Corbalán, los virtuosismos anamórficos habrían surgido más bien cuando se codifica y domina el arte y la técnica de la perspectiva, es decir al comienzo de la geometría proyectiva ${ }^{15}$. Sea como fuere, es indudable que existe una estrecha correlación entre la moda anamórfica que se apoderó del siglo XVII y el nacimiento de la nueva geometría en esos mismos años. El propio Baltrusaitis ya apuntó que si bien Desargues y su continuador Abraham Bosse no incluyeron en sus trabajos formas desnaturalizadas al plantear sus procedimientos, no deja por ello de ser evidente que la operación que proponían ambos «utiliza fuertes deformaciones, que su práctica de proyección se basa en el principio que Barbaro preconizó para las anamorfosis, y que finalmente está concebida pensando en vastas superficies arquitectónicas donde los Mínimos introducían los juegos ópticos precisamente en esta época» ${ }^{16}$. Al fin y al cabo, Desargues mantenía una estrecha relación con Mersenne y con todos los eruditos de este convento.

La anamorfosis puede ser considerada sin temor a exagerar como un emblema artístico del cambio que supuso la aparición de la geometría proyectiva. Un giro sin duda revolucionario ya que en lugar de mostrar a la manera de Jean Pèlerin Viator a costa de qué desplazamiento del lugar perceptivo se podían enderezar las deformaciones perspectivas, en sus cónicas Desargues presentó estas deformaciones (circunferencia, elipse, parábola, hipérbole) de forma serial, como pertenecientes a un mismo «género», a la vez que aportaba la operación necesaria para pasar de un elemento a otro convirtiendo el conjunto en lo que Pierre Magnard se ve autorizado «a llamar anacrónicamente un grupo de transformaciones». Por ello, según este, con Desargues «se asiste a una verdadera revolución

\footnotetext{
${ }^{14}$ Gérard Chazal, Les médiations théoriques. Seyssel, Champ Vallon, 2004, p. 34.

${ }^{15}$ Denis Favennec, Douce perspective. Paris, Ellipses, 2007; Fernando Corbalán, Matemáticas de la vida misma. Barcelona, Grao, 2007, pp. 158-159.

${ }^{16}$ Jurgis Baltrusaitis, op. cit., p. 104.
} 
copernicana, cuando ya no es el punto de vista el que gira alrededor del motivo, en busca de la posición que enderezará la anamorfosis, sino que es el motivo el que desenrolla la serie de apariencias delante de la mirada inmóvil de una mente capaz de aprehender su razón» ${ }^{17}$. Un giro que marca el inicio de una visión moderna del mundo. Lamentablemente, debido a la utilización de un lenguaje demasiado innovador que le valió la reputación de demente entre el resto de los matemáticos de su tiempo, pero también por recurrir a unas técnicas muy diferentes del análisis algebraico que Descartes había introducido con enorme éxito, la revolución de Desargues apenas se hizo notar, salvo en la influencia que dejó en su discípulo inmediato Blaise Pascal y en el seguidor más tardío Philippe de La Hire. De hecho, las implicaciones matemáticas de sus trabajos no se empezaron a percibir hasta comienzos del siglo XIX cuando Poncelet resucitó la geometría proyectiva al comprender que se trataba de una nueva rama de las matemáticas.

\section{Arte y ciencia de las distorsiones topológicas}

Hoy sabemos que la geometría proyectiva, cuyos cimientos había levantado en silencio Desargues a partir de los trabajos de los artistas renacentistas que habían pretendido pintar un mundo tridimensional en una tela de dos dimensiones, desempeña un papel fundamental en la geometría. Así lo puso de manifiesto Morris Kline en un espléndido artículo en el que abordaba el origen artístico de esta geometría y su alcance en distintas disciplinas. En primer lugar, comparadas con las propiedades de la geometría euclídea — que trata de la igualdad de distancias, ángulos y áreas-, las propiedades que no varían en proyección y sección resultan mucho más sencillas. Por ello, argumenta Kline «se podría decir que la geometría proyectiva trata de la formación misma de figuras geométricas cuya congruencia, semejanza y equivalencia (igualdad de áreas) se estudian con Euclides. En otras palabras, la geometría proyectiva es más fundamental que la geometría euclídea» ${ }^{18}$. En segundo lugar, los matemáticos Klein y Cayley mostraron que las geometrías no euclídeas de Lobachevsky y Bolyai, asî como la creada por Reimann «pueden derivarse también como casos especiales de la geometría proyectiva». Esta afinidad de la geometría proyectiva con las geometrías euclídea y no euclídea, demostrada a finales del siglo XIX, prosigue Kline, sugirió la existencia de una nueva forma de aproximarse a la geometría: «La proyección y sección son lo que se llama una transformación; es decir, se empieza con una figura dada, se forma una proyección desde algún punto central y se obtiene una sección de esta proyección. El proceso entero que traslada una de las figuras originales a la sección, es la transformación». Ahora bien, los matemáticos no tardaron en preguntarse si no existirían «otras transformaciones más generales que la proyección y sección, cuyas propiedades invariables pueden ser estudiadas» y siguiendo esta línea de pensamiento nació una nueva geometría, conocida en la actualidad con el nombre de topología ${ }^{19}$. Así pues, la geometría proyectiva, nacida en correlación con

\footnotetext{
${ }^{17}$ Pierre Magnard, «L'invention de la perspective. Un geste métaphysique inaugural des Temps modernes», en Ph. Soual, ed., Expérience et métaphysique dans les cartésianisme. Paris, L’Harmattan, 2007, p. 96.

${ }^{18}$ Morris Kline, «Geometría proyectiva», en Sigma. El mundo de las matemáticas. Barcelona, Grijalbo, 1969, p. 233.

${ }^{19}$ Ibíd., pp. 234-235.
} 
las anamorfosis durante el siglo XVII, proporcionó finalmente una metodología más adecuada a la geometría euclídea y no euclídea, y aportó un marco teórico que permitió la emergencia de la topología a finales del siglo XIX. Disciplinas de las matemáticas todas ellas que Henri Poincaré contribuyó sensiblemente a desarrollar con su imaginación visual. La figura del eminente matemático francés vuelve a hacer su aparición.

El propio Poincaré establecía en uno de sus últimos artículos una especie de jerarquía entre las distintas clases de geometría. Así como la geometría métrica está fundada en la noción de distancia, la geometría proyectiva lo está en la noción de línea recta. En este caso, explicaba, "para que dos figuras sean consideradas equivalentes no es necesario que sean iguales, basta que se pueda pasar de una a otra por una transformación proyectiva, es decir, que una sea la perspectiva de la otra» ${ }^{20}$. Como la medida y la cantidad desempeñan un papel menos importante que en la geometría métrica se ha llamado frecuentemente geometría cualitativa a este cuerpo de doctrina, pero tal designación es totalmente errónea en opinión de Poincaré, pues que una línea sea recta no es un hecho cualitativo y no podría asegurarse sin un instrumento de medida como una regla. Existe, en cambio,

[...] una tercera geometría que es puramente cualitativa y de la cual está completamente desterrada la cantidad: es el Análisis Situs. En esta disciplina, dos figuras son equivalentes siempre que se pueda pasar de una a otra por una deformación continua, cualquiera que sea, por otra parte, la ley de esta deformación, con tal que respete la continuidad. Así una circunferencia es equivalente a una elipse o aun a una curva cerrada cualquiera, pero no lo es a un segmento de recta, porque este no es cerrado. ${ }^{21}$

Esta geometría conocida en la actualidad con el nombre de topología, a cuyo pleno desarrollo contribuyó de forma decisiva Poincaré, tiene al igual que las demás geometrías a las formas espaciales como objeto, pero considerándolas en cambio únicamente desde un punto de vista cualitativo. Y es que, como ya vimos, el arte de la anamorfosis guarda con la topología una estrecha relación.

Las imágenes reflejadas en aquellos espejos deformantes que antaño abundaban en las ferias son distorsiones topológicas, como lo ha subrayado Franco Agostini, puesto que «desde un punto de vista topológico las personas y sus imágenes deformadas son las mismas entidades geométricas», pudiendo «establecerse entre ellas una correspondencia biunívoca» ${ }^{22}$. En el ámbito de la topología no es cuestión de medidas, sino, en palabras de Gérard Chazal, «de orientación, de vecindad, de deformaciones continuas, de anamorfosis sin rupturas» ${ }^{23}$. En este sentido, podría decirse que las anamorfosis, que proliferaron cuando nació la geometría proyectiva —esa relativa geometría cualitativa-, son distorsiones topológicas realizadas por un artista y por ello poseen cualidades estéticas. No parece casual, pues, que para ilustrar la naturaleza de esta nueva geometría cualitativa Poincaré ofreciera en el artículo anteriormente citado un ejemplo sacado del campo de las artes al que ya había recurrido al menos en otras dos ocasiones: «Supongamos un modelo cualquiera y la copia del mismo ejecutada por un dibujante inhábil; las proporciones están alteradas, las rectas trazadas por una mano temblorosa han

\footnotetext{
${ }^{20}$ Henri Poincaré, «¿Por qué el espacio tiene tres dimensiones?», en Últimos pensamientos. Buenos Aires, Espasa-Calpe, 1946, pp. 50-51.

${ }^{21}$ Ibíd., p. 51.

${ }^{22}$ Franco Agostini, Juegos de lógica y matemáticas. Madrid, Pirámide, 1987, p. 64.

${ }^{23}$ Gérard Chazal, Formes, figures, réalité. Seyssel, Champ Vallon, 1997, p. 107.
} 
sufrido deformaciones molestas y presentan curvaturas desastrosas. Desde el punto de vista de la geometría métrica, desde el de la misma geometría proyectiva, las dos figuras no son equivalentes; por el contrario, lo son desde el punto de vista del análisis situs» ${ }^{24}$. Del mismo modo que al pintar una cosa hueca y alargada Holbein había ofrecido en Los embajadores una copia fiel aunque distorsionada de una calavera, el dibujante mediocre imaginario de Poincaré realiza una copia perfecta del modelo original desde un punto de vista topológico. Para hacer aun más claro el ejemplo de Poincaré, Kasner y Newman representaron en Matemáticas e imaginación un triángulo plano y su copia topológicamente perfecta a la que designaron como su «gemelo distorsionado surrealista» en el que las líneas rectas se volvían curvas, los ángulos estaban cambiados y deformados, y las longitudes de los lados alteradas, aunque sus propiedades geométricas comunes no variaban ${ }^{25}$. A simple vista la figura resultante guardaba incluso menos parecido con un triángulo que los relojes blandos de Dalí con un Rolex.

La topología algebraica, rama de las matemáticas que concierne a las propiedades invariantes de una figura deformada de modo continuo, nació verdaderamente con Poincaré. Hasta entonces, salvo los trabajos pioneros de Riemann y Betti, esta disciplina había suscitado escaso interés, pero en el caso de Poincaré, como él mismo confesaba, «todos los caminos diversos en los que me internaba sucesivamente me conducían al Analysis situs» ${ }^{26}$. No es casual que se topara una y otra vez con esta disciplina ni que fuera precisamente él quien acabase devolviéndole a las matemáticas la imaginación visual que habían perdido, pues más que cualquier otro matemático de su tiempo Poincaré tenía una concepción artística de las matemáticas que procedía en buena medida de su formación humanística. Si hasta el siglo XVII había predominado un enfoque visual de las matemáticas, geométrico, paulatinamente fue imponiéndose un estilo más formal y los dibujos y diagramas fueron escaseando, reemplazados por fórmulas, cálculos y métodos analíticos. Poincaré, quien había dedicado uno de sus numerosos trabajos a poner de manifiesto la necesaria complementariedad de «analistas» y «geómetras», de «lógicos» e «intuitivos», en el desarrollo de la ciencia, pertenecía sin duda al tipo de matemático que, según su propia expresión, «piensa con imágenes» ${ }^{27}$. Según él, para ayudar a la intuición que tan indispensable resultaba en la invención matemática, «el geómetra tiene necesidad de dibujar figuras, o por lo menos de representárselas mentalmente. Ahora bien, si se desentiende ventajosamente de las propiedades métricas o proyectivas de esas figuras, si se dedica únicamente a sus propiedades puramente cualitativas, se debe a que solo allí interviene verdaderamente la intuición geométrica» ${ }^{28}$. Para Poincaré el topólogo es una suerte de dibujante de mirada anamórfica.

Es más que probable que Poincaré tuviera conocimiento de los tratados matemáticos de los perspectores del siglo XVII como Niceron y que hubiese consultado los trabajos de geometría proyectiva de Desargues que acababan de ser redescubiertos, pero en cualquier caso es indudable que

\footnotetext{
${ }^{24}$ Henri Poincaré, op. cit., p. 51.

${ }^{25}$ Edward Kasner y James Newman, Matemáticas e imaginación. Barcelona, Orbis, 1987, p. 270.

${ }^{26}$ Henri Poincaré, Oeuvres. Paris, Gauthier-Villars, 1953, vol. vI, p. 183.

${ }^{27}$ Henri Poincaré, «Du rôle de l'intuition et de la logique en mathématiques», en E. Duporcq, ed., Compte rendu du deuxième Congrès international des mathématiciens, tenu à Paris du 6 au 12 août 1900. Paris, Gauthier-Villars, 1902, p. 117.

${ }^{28}$ Henri Poincaré, «¿Por qué el espacio tiene tres dimensiones?», en Últimos pensamientos, op. cit., p. 52.
} 
el pensamiento anamórfico recorre el conjunto de su obra matemática e incluso puede decirse que en buena medida descansa sobre él. Así, por ejemplo, después de reivindicar la naturaleza estética de las matemáticas y reclamar que el matemático trabaje como un artista, Poincaré sostenía que la finalidad de la física matemática era dar a conocer al físico «la armonía oculta de las cosas haciéndoselas ver de forma oblicua ${ }^{29}$. Pura revelación anamórfica. Pero Poincaré llega asimismo a hacer alusión explícita a una imagen anamórfica convirtiéndola incluso en metáfora de la relatividad del espacio:

Si mirásemos el mundo en uno de esos espejos de forma complicada que deforman los objetos de un modo extraño, las relaciones mutuas de las diversas partes de este mundo no estarían por ello alteradas; si, en efecto, dos objetos reales se tocan, sus imágenes parecen igualmente tocarse. A decir verdad, cuando miramos en semejante espejo, percibimos efectivamente la deformación, pero es porque el mundo real subsiste al lado de su imagen deformada; e incluso si este mundo real nos fuese escondido, hay algo que no podrían escondernos, y es a nosotros mismos; no podemos dejar de ver, o al menos de sentir, nuestro cuerpo y nuestros miembros que no han sido deformados y que continúan sirviéndonos de instrumentos de medida. Pero si imaginamos que nuestro cuerpo esté él mismo deformado, y del mismo modo que si fuera visto en el espejo, a su vez nos faltarán estos instrumentos de medida y la deformación no podrá ya ser constatada. ${ }^{30}$

Poincaré convierte el universo en un auténtico gabinete de curiosidades al proyectarlo en un espejo deformante. En este caso la anamorfosis a la que alude es mucho más que un simple ejemplo ya que su lógica revela la forma en la que se han de abordar las geometrías no euclídeas. En efecto, acto seguido Poincaré imaginaba que mediante una «transformación puntual» se pusiesen en correspondencia dos a dos los puntos de dos mundos diferentes pero que resultarían por ello indiscernibles el uno del otro. Dado que un mundo es la imagen del otro la geometría que construirían los habitantes del mundo A sería la misma que la del mundo B. Pero si un día se abriese una ventana que los pusiera en contacto los habitantes de cada mundo no podrían dejar de apiadarse los unos de los otros: pobres desgraciados, dirían, «creen haber hecho una geometría, pero lo que llaman así no es más que una imagen grotesca de la nuestra; sus rectas están todas torcidas, sus círculos son jorobas, sus esferas tienen caprichosas desigualdades» ${ }^{31}$. Poincaré ya había mostrado las consecuencias que había que sacar de estos hechos para hacerse una idea justa de las geometrías no euclídeas que hasta entonces parecían simples aberraciones o extravagancias.

Para Poincaré una geometría no es más verdadera que otra, tan solo puede ser más cómoda. En nuestro mundo la geometría euclídea es la más simple y la que mejor concuerda con las propiedades de los sólidos y de nuestro cuerpo, y por ello es la más conveniente. Con el objeto de representar de modo euclídeo la geometría hiperbólica, que es no euclídea, el matemático francés ideó un modelo conocido como «disco de Poincaré» en el que las geodésicas (líneas rectas) aparecen torcidas y que constituye una nueva modalidad de anamorfosis. El famoso pintor holandés M. C. Escher, basándose en las explicaciones que el matemático H. S. M. Coxeter le había dado de este modelo, creó el cuadro Límite circular IV, popularmente conocido como Ángeles y demonios y que da una perfecta idea del universo anamórfico de Poincaré. En esta obra Escher representó un mosaico de ángeles blancos y

\footnotetext{
${ }^{29}$ Henri Poincaré, La valeur de la science. Paris, Flammarion, 1970, p. 108.

${ }^{30}$ Henri Poincaré, Science et méthode. Paris, Flammarion, 1947, p. 101.

${ }^{31}$ Ibíd.
} 
demonios negros que disminuyen de tamaño a medida que se alejan del centro del disco en el que aparecen hasta terminar perdiéndose en los bordes. Ahora bien, como advierte Robert Osserman, en realidad «todos los ángeles son copias exactas los unos de los otros si se consideran en la verdadera escala del plano de Lobachevski». Y otro tanto sucede con los demonios: «todos ellos son del mismo tamaño y forma en la "geometría imaginaria" y solo varía su tamaño en el dibujo» ${ }^{32}$ donde aparecen distorsionadas las longitudes y distancias. Inextricablemente ensamblados entre sí, los ángeles y los demonios tienen la misma dimensión en el universo no euclídeo al que pertenecen. Para poder servirse de la geometría no euclídea en tres dimensiones Poincaré había imaginado un modelo anamórfico cuya representación incluso había inspirado a un artista de la talla de Escher. Y es que el arte, y el arte de la anamorfosis en particular, estaban estrechamente vinculados a su filosofía matemática.

\section{Poincaré y las bellas artes matemáticas}

Poincaré hizo aflorar una corriente visual de las matemáticas que permanecía oculta desde la época de Desargues, cuando matemático y artista todavía se compenetraban en sus trabajos. El autor de La ciencia y la hipótesis fue sin duda uno de los más grandes matemáticos de todos los tiempos y uno de los últimos en dominar tantas ramas diferentes de la ciencia antes del triunfo de la especialización. Espíritu unificador en el mundo de las ciencias y fuera de ellas, se le considera con justicia como un auténtico humanista que nunca dejó de mostrarse convencido de que no existía razón alguna que justificara la separación de las ciencias y las artes. No solo veía en la ciencia una oportunidad que se le brindaba a todo poeta para cultivar el misterio, sino que a la inversa, y de forma mucho más singular, lejos de considerar las artes y las letras como simples medios de entretenimiento, aseguraba que eran indispensables para la existencia del hombre común y especialmente para la formación del científico. En uno de sus artículos más significativos a este respecto, «Las ciencias y las humanidades», defendía la necesidad de que los jóvenes matemáticos estudiaran análisis gramatical, supieran apreciar la perfecta elección de los términos de los poetas y sobre todo aprendieran a traducir las lenguas clásicas para cultivar con esta práctica su espíritu matemático en toda su plenitud ${ }^{33}$. Sumirse en los mundos literarios y aprender a admirar las bellas artes era a juicio de Poincaré la mejor forma de desarrollar el esprit de finesse que tanto necesitan los matemáticos.

Para Henri Poincaré la obra de arte era la manifestación más apropiada para adquirir la sensibilidad sin la cual la invención matemática sería pura quimera. Porque, en su opinión, las matemáticas son asimismo un arte: «El científico digno de este nombre, el geómetra sobre todo, siente frente a su obra la misma impresión que el artista; su goce es tan grande y de la misma naturaleza» ${ }^{34}$.

\footnotetext{
${ }^{32}$ Robert Osserman, La poesía del universo. Barcelona, Crítica, 1997, p. 81.

${ }^{33}$ Acerca del valor que Poincaré otorgaba a la traducción y a las humanidades, puede consultarse mi artículo «El diccionario romántico de Poincaré», en Amelia Gamoneda, ed., Espectro de la analogía. Literatura y ciencia. Madrid, Abada, 2015, pp. 17-92.

${ }^{34}$ Henri Poincaré, Savants et écrivains. Paris, Flammarion, 1910, p. 138.
} 
Lo que le mueve no es la utilidad sino el placer estético. Los adeptos a las matemáticas encuentran en esta disciplina

[...] goces análogos a aquellos que otorgan la pintura y la música. Admiran la delicada armonía de los números y de las formas; se maravillan cuando un nuevo descubrimiento les abre una perspectiva inesperada; y la alegría que sienten de este modo, ¿no tiene acaso el carácter estético, aunque los sentidos no tomen ninguna parte en ello? Pocos privilegiados están llamados a disfrutarlo plenamente, es cierto, pero ¿acaso no es lo que sucede para las artes más nobles? ${ }^{35}$

Así pues, es una especie de belleza intelectual «lo que nos hace elegir los hechos que mejor contribuyen a la armonía, de la misma forma que el artista elige, entre los rasgos de su modelo, aquellos que completan el retrato y le dan el carácter y la vida» ${ }^{36}$.

No debería sorprender encontrar tantos símiles pictóricos bajo la pluma de quien acertó a resucitar las imágenes visuales para el trabajo del matemático. Como ya hemos tenido ocasión de ver, abundan en efecto, de forma significativa, en los escritos de Poincaré las alusiones a la pintura y a la figura del pintor como imagen de la actividad matemática. El pintor es presentado a menudo como espejo del matemático: «Si se me permite seguir mi comparación con las bellas artes, el matemático puro que olvidase la existencia del mundo exterior, sería semejante a un pintor que supiera combinar armoniosamente los colores y las formas, pero a quien le faltasen los modelos. Su potencia creadora pronto estaría agotada» ${ }^{37}$. Pero sería un error pensar que la pintura es para él un simple pretexto para formular sus ideas matemáticas de forma amena, pues Poincaré apreciaba las bellas artes e incluso se mostraba atento a las innovaciones en esta materia.

Así, cuando sostiene que el matemático debería saber analizar los componentes de una frase para entender el enunciado de un problema en todos sus matices, se vale de la pintura de vanguardia para ilustrar cómo por el contrario captamos normalmente el sentido de una frase de un solo vistazo. En estos casos «las diversas palabras de una misma frase resplandecen al mismo tiempo; sus luces se mezclan; los campos que iluminan montan uno sobre otro, sin que pueda decirse de cuál de todos estos faros tal o cual punto extrae más luz». Comprender una frase de este modo significa «ver como lo hace el miope a quien los diversos puntos del objeto aparecen como manchas que desbordan las unas sobre las otras e iguales a las que se admiran en ciertos cuadros modernos» ${ }^{38}$. Aunque Poincaré no especifica la autoría de los cuadros a los que se refiere no es difícil adivinar a través de su descripción qué pintores tiene en mente. Sin duda está pensando en primer lugar en Cézanne pero también en sus más directos herederos, los cubistas. Con su pintura arquitectónica en la que cada tono se colorea con el siguiente en la yuxtaposición y superposición de cada pincelada, en la que las fluctuaciones de la luz engullen los contornos de las cosas haciendo que los planos caigan los unos sobre otros, Cézanne había logrado que las formas adquirieran volúmenes geométricos y los objetos parecieran ser vistos desde dos ángulos diferentes si bien integrados en una composición unitaria. Un momento decisivo en la historia

\footnotetext{
${ }^{35}$ Henri Poincaré, La valeur de la science, op. cit., p. 104.

${ }^{36}$ Henri Poincaré, Science et méthode, op. cit., p. 16.

${ }^{37}$ Henri Poincaré, La valeur de la science, op. cit., p. 109.

${ }^{38}$ Henri Poincaré, Les sciences et les humanités. Paris, Arthème Fayard, 1911, p. 12.
} 
Las anamorfosis de Poincaré: una mirada oblicua a las matemáticas, la pintura y la poesía

de la pintura porque marcaba el final de la visión sometida a un punto de vista único heredado del Renacimiento y anunciaba ya el espacio de múltiples dimensiones del cubismo.

\section{La huella cubista de Poincaré}

No deja de ser singular y significativo a un tiempo que Poincaré evocase a modo de ejemplo precisamente unos cuadros cuyo original estilo había encontrado en sus propias teorías matemáticas, cuando menos, un aval científico. En un ensayo magnífico, en el que aborda la naturaleza de la cuarta dimensión desde sus múltiples facetas (matemática, cultural, literaria y artística), Raúl Ibáñez ha mostrado cómo los cubistas, que querían romper con la perspectiva que había dominado la pintura desde el Renacimiento, se habían inspirado en las geometrías no euclídeas y en las geometrías multidimensionales para llevar hasta sus últimas consecuencias la revolución que había emprendido Cézanne $^{39}$. A estas teorías habían accedido los cubistas justamente a través de los libros de divulgación de Henri Poincaré. Como ha puesto de manifiesto con gran acierto Alfonso Palacios, el matemático francés desempeñó un papel de primer orden en los intentos llevados a cabo por algunos cubistas de plasmar una realidad instalada en una dimensión superior; sus obras La ciencia y la hipótesis y El valor de la ciencia «se convirtieron, por su claridad expositiva, en textos de referencia para muchos de los artistas adscritos a este movimiento» ${ }^{40}$. De entre estos artistas que encontraron inspiración en las ideas de Poincaré destacan dos figuras antitéticas que marcaron con sus obras el destino del arte de todo el siglo XX: Picasso y Duchamp.

Con Las señoritas de Aviñón (1907) Pablo Picasso dio un salto sin precedentes en la historia del arte al avanzar hacia el lenguaje geométrico del cubismo naciente tomando esencialmente como guías las ciencias y las matemáticas. Y en este sentido, como ha mostrado Arthur I. Miller, el análisis que realizó Picasso del mundo tetradimensional de Poincaré fue determinante para la concepción de su famoso cuadro. Parece sin embargo que Picasso no leyó directamente las obras de Poincaré sino que las ideas de este le fueron transmitidas de viva voz por Maurice Princet, «el matemático del cubismo»: «fue Poincaré, a través de Princet, quien facilitó los detalles sobre el significado de la geometría no euclídea y un atisbo sobre el contenido de la cuarta dimensión» ${ }^{41}$ a Picasso y a sus compañeros. Sin duda el pintor malagueño debió de encontrar muy sugerentes las ideas de Poincaré sobre la cuarta dimensión, especialmente cuando este recurría a imágenes pictóricas para tratar de ilustrar algo tan abstracto. En efecto, en La ciencia y la hipótesis el matemático sostenía que

[...] del mismo modo que se puede hacer sobre un plano la perspectiva de una figura de tres dimensiones, se puede hacer la de una figura de cuatro dimensiones sobre un lienzo de tres (o de dos) dimensiones. Solo es un juego para el geómetra. Se puede incluso tomar de una misma figura varias perspectivas de varios puntos de vista diferentes. Podemos fácilmente representarnos estas perspectivas puesto que no tienen más que tres dimensiones. Imaginemos que las diversas perspectivas de un mismo objeto se suceden las unas a las otras; que el paso de la una a la otra esté acompañado por sensaciones musculares. [...] No hay nada en esto que no se pueda representar y sin embargo estas sensaciones son precisamente las que tendría un ser provisto de

\footnotetext{
${ }^{39}$ Raúl Ibáñez Torres, La cuarta dimensión. ¿Es nuestro universo la sombra de otro? Barcelona, RBA, 2011.

${ }^{40}$ Alfonso Palacios Álvarez, El manifiesto dimensionista 1936. Oviedo, Museo de Bellas Artes de Asturias, 2003 , p. 19.

${ }^{41}$ Arthur I. Miller, Einstein y Picasso. El espacio, el tiempo y los estragos de la belleza. Barcelona, Tusquets, 2007, p. 125.
} 
una retina de dos dimensiones y que podría desplazarse en el espacio de cuatro dimensiones. Está permitido en este sentido decir que se podría representar la cuarta dimensión. ${ }^{42}$

Ahora bien, según Miller, Picasso entendió que el mundo tetradimensional no debía de aparecer de forma sucesiva como lo proponía Poincaré sino simultáneamente, es decir mostrando en efecto lo representado desde sus múltiples perspectivas pero a un mismo tiempo: «A la sugerencia de Poincaré en el sentido de que la cuarta dimensión se representara como una sucesión de escenas, Picasso añadió un ingenioso giro visual: colocar diferentes vistas en una escena, todas a la vez, de manera

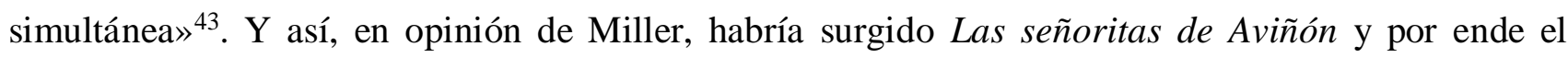
cubismo. Unos años más tarde, Marcel Duchamp, miembro entonces del grupo cubista de Puteaux cuyos intereses giraban en torno a la cuarta dimensión, optó en cambio por seguir más fielmente la descripción multidimensional de Poincaré al representar en su polémico Desnudo bajando una escalera una figura desde diversas perspectivas sucediéndose las unas a las otras. No es de extrañar porque, como ha mostrado Linda Henderson, Poincaré fue para Duchamp una fuente de inspiración de primera importancia. Además de encontrar en su filosofía convencionalista un estímulo para atentar «contra los absolutismos matemáticos o estéticos» ${ }^{44}$, Duchamp adquirió en los escritos de Poincaré, así como en los de Jouffret y en la novela de Pawlovski Viaje a la cuarta dimensión, un conocimiento de las geometrías no euclídeas y de la cuarta dimensión que se plasmaría en su obra de mayor prestigio, El Gran Vidrio.

La mariée mise à nue par ses célibataires, même (1915-1923) consta, como es sabido, de dos cristales superpuestos, separados por un doble filo de plomo, pintados al óleo. El todo constituye un rectángulo de 3,99945 $\mathrm{m}^{2}$ conocido por ello también como El Gran Vidrio. Como si se tratara de un aparato (y es en efecto un complejo mecanismo), este hermético cuadro viene asimismo acompañado de una Caja verde que incluye reproducciones de los diversos estudios y numerosas notas que confeccionó el propio Duchamp a modo de irónico manual de instrucciones. En estas notas, así como en las que se incluyen en la Caja blanca, publicadas para ser leídas en conjunción con el cuadro, se hace patente que El Gran Vidrio es un artefacto de grandes dimensiones, y no solo en el sentido métrico de la palabra.

El cuadro de Duchamp ha sido ya tantas veces estudiado en detalle que bastará aquí recordar que, como había sugerido el propio artista, la parte superior del Vidrio es pura apariencia ya que corresponde a la proyección en tres dimensiones de la Novia, un ser que a su vez habita en un universo de cuatro dimensiones, mientras que la parte inferior representa el dominio de dos y tres dimensiones de los solteros que se ven sometidos así a los rigores de nuestra geometría euclídea. Lejos de ser una vaga idea, este juego de proyecciones de las formas auténticas que pueblan las dimensiones superiores, de inspiración platónica sin duda, descansa sobre una profunda investigación acerca de la perspectiva y de las geometrías muldimensionales que llevó a cabo Duchamp durante una larga temporada. Así lo

\footnotetext{
${ }^{42}$ Henri Poincaré, La Science et l'Hypothèse. Paris, Flammarion, 1968, pp. 92-93.

${ }^{43}$ Arthur I. Miller, op. cit., pp.209-210.

${ }^{44}$ Linda Dalrymple Henderson, Duchamp in Context. Science and Technology in the Large Glasse and Related Works. Princeton, Princeton University Press, 1998, pp. 187-188.
} 
confirma la lectura de En infinitivo (Caja blanca) donde, como ha señalado Calvin Tomkins, la mitad de las notas de Duchamp tratan de la perspectiva y de la cuarta dimensión ${ }^{45}$. Entre estas anotaciones encontramos en varias ocasiones referencias explícitas a las ideas de Poincaré, como en el siguiente caso: «La explicación de Poincaré de los continuos n-dimensiones por el corte de los continuos de n-1 dimensiones no incurre en error. Está confirmada, al contrario, y será incluso apoyándose en esa explicación como podamos justificar la denominación de $4^{\mathrm{a}}$ dimensión dada a este continuo de imágenes virtuales en donde el corte solo podría obtenerse por el objeto tipo de 3 dimensiones, considerado en su infinito geométrico» ${ }^{46}$. Estas imágenes virtuales habrían de materializarse en la obra de Duchamp como reflejos en el cristal.

Pero junto a estas lecturas de los escritos de Poincaré es interesante señalar que abundan asimismo las referencias al arte de la perspectiva entre estos papeles. Duchamp se enfrascó en la biblioteca Sainte-Geneviève en el estudio acelerado de la perspectiva de origen renacentista que pretendía crear la ilusión de las tres dimensiones en un lienzo bidimensional, y que los artistas modernos habían desechado con vehemencia. Por ello, no podía dejar de interesarse por las obras de los perspectores del siglo XVII y en particular por la Perspectiva curiosa de Niceron a la que alude en sus notas ${ }^{47}$. En Apariencia desnuda, aún hoy uno de los mejores estudios que se han escrito sobre la obra de Duchamp, Octavio Paz no solo subrayó la fuerte impronta que las ideas sobre la cuarta dimensión de Poincaré habían dejado en El Gran Vidrio sino que además puso de manifiesto el parentesco existente entre las concepciones que originaron esta obra y los trabajos que Niceron y el círculo de Mersenne dedicaron a la anamorfosis. Y es que La novia desnudada por sus Solteros, incluso... se inscribe en la tradición de aquellas perspectivas curiosas inaugurada a lo largo del siglo XVII, es incluso uno de sus últimos y más logrados avatares. Contemplada esta obra en todas sus dimensiones, resulta ser, en palabras del poeta mejicano, «una anamorfosis, en el sentido literal de esta palabra; ver esta obra en sus formas sucesivas es remontar hacia la forma original, la verdadera, la fuente de las apariencias». Y como aquí cambian las formas pero no las esencias, El Gran Vidrio es una «Universal anamorfosis: cada forma que vemos es la proyección, la imagen deformada, de otra» ${ }^{48}$.

Reuniendo en un lienzo doble y singular el universo anamórfico de Niceron y el universo muldimensional de Poincaré, Duchamp realizó una cristalización de la historia misma del arte de la perspectiva, desde el momento en que Desargues inventa la geometría proyectiva hasta el momento en que Poincaré legitima la existencia de las geometrías no euclídeas y la cuarta dimensión para el arte. El Gran Vidrio como anamorfosis apoteósica de la historia de la pintura.

\footnotetext{
${ }^{45}$ Calvin Tomkins, Duchamp. Barcelona, Anagrama, 1999, p. 144.

${ }^{46}$ Marcel Duchamp, Escritos. Duchamp du signe. Barcelona, Gustavo Gili, 1978, p. 122.

${ }^{47}$ Ibíd., p. 109.

${ }^{48}$ Octavio Paz, Apariencia desnuda. La obra de Marcel Duchamp. México, Era, 1978, pp. 10 y 70.
} 


\section{Poincaré en el espejo cilíndrico de Cocteau}

Del mismo modo que con su geometría proyectiva Desargues había tratado de dar respuesta matemática a las cuestiones de perspectiva que habían planteado los artistas desde el Renacimiento, las teorías de Poincaré dieron carta de naturaleza científica a los experimentos artísticos que desde finales del siglo XIX venían realizando los pintores modernos. La nómina de los artistas que hallaron en los escritos de Poincaré fundamentos para desarrollar su obra es extensa: además de los pintores a los que hemos hecho ya referencia (Picasso, Duchamp, Escher), no podemos dejar de evocar aquí al pintor futurista Gino Severini, al mejicano Diego Rivera en su etapa cubista y de forma muy particular a Theo Van Doesburg, fundador del movimiento de abstracción geométrica De Stijl en cuya revista homónima llegó incluso a reproducir en 1923 un artículo completo del matemático francés. No menos determinante y abundante fue el impacto de Poincaré sobre los escritores de su tiempo. De entre todos ellos merece especial atención para nuestro propósito el poeta, novelista, dramaturgo, pintor y cineasta Jean Cocteau. Y es que este polifacético artista no solo vinculó a Poincaré y su obra con el arte de la anamorfosis sino que además supo apropiarse de esta imagen perspectiva para expresar el necesario encuentro de la poesía y de la ciencia.

Aunque Cocteau formó parte del entorno de Picasso y de los cubistas — con los que entró en contacto desde 1915 y que tanto influyeron en su arte-, no fueron estos quienes le dieron a conocer las ideas de Poincaré. En efecto, en 1912, cuando era todavía un joven y anónimo poeta, conoció personalmente a tan venerable matemático, y las palabras que este le dirigió entonces habrían de cobrar con el tiempo un gran valor en su concepción del arte. El propio Cocteau menciona este encuentro por primera vez en su primera novela, El Potomak:

Allí donde un muro obliga a los filósofos y los científicos a meticulosas paradas comienza el poeta.

La ciencia no sirve más que para verificar los descubrimientos del instinto.

Quisiera citarles dos frases. Me fueron dichas por H. Poincaré algunos días antes de su muerte. Yo era bien joven y me había encontrado con él en casa de Alysse. He aquí la primera: «¿Por qué habría de ser usted tímido? Soy yo quien debería serlo. Su juventud y su poesía son dos privilegios. El azar de una rima extrae a veces un sistema de la sombra, y la alegría atrapa el misterio al vuelo». La segunda era mejor:

«Sí, sí, dijo este hombre íntegro, entiendo. Usted querría saber en qué punto nos encontramos con lo desconocido. Cada día trae un prodigio a nuestros laboratorios, pero la responsabilidad nos obliga al silencio profesional. Veo cosas, veo cosas... (Y retiró sus anteojos.) La fe que deposita la gente en nosotros únicamente puede alimentarse de certidumbre. ¡Lo desconocido!...».

Oigo el samovar y un bateau-mouche sobre el Sena.

«Significa en relación a nosotros, en el momento actual, lo mismo que para los mineros que excavan una galería, el golpe seco, los primeros picotazos de los mineros que vienen a su encuentro». ${ }^{49}$

Escuchar a la edad de veintitrés años semejante discurso en el que uno de los más prestigiosos matemáticos de la época reconocía abiertamente los límites de la ciencia y reivindicaba el papel supremo de la poesía en el descubrimiento de lo misterioso, dejó en el joven Cocteau una huella profunda e indeleble. De hecho, una década más tarde el poeta volvería a referir en El secreto profesional la primera de estas frases que le había dicho Poincaré, si bien no atreviéndose a comentarla

${ }^{49}$ Jean Cocteau, Le Potomak, en Euvres romanesques complètes. Paris, Gallimard, 2006, p. 35. 
por ser a su parecer demasiado magistral ${ }^{50}$. Por ello, tiene razón Jacques Brosse cuando, a la hora de constatar los encuentros que fueron determinantes en el desarrollo de Jean Cocteau, señalaba junto a las figuras de Picasso, Diaghilev, Stravinski o Satie a Henri Poincaré y, más concretamente, lo que este le había revelado sobre el valor heurístico del poema al tratarse de una «frase clave que Cocteau retomará bajo diversas formas en toda su obra, y que, más tarde, justificará retrospectivamente las extrapolaciones científicas del Diario de un desconocido» ${ }^{51}$.

En efecto, este último ensayo de temática caleidoscópica, a imagen y semejanza de la personalidad «cubista» de su autor, está recorrido como en filigrana por abundantes reflexiones sobre los misterios de las ciencias contemporáneas. No es de extrañar por lo tanto que desde las primeras páginas Cocteau se pusiera bajo la tutela de Poincaré:

Un eminente científico [Poincaré] me dijo un día que se tenían más contactos con el misterio si uno no se deja encorsetar por las doctrinas, con la suerte, si uno tira la moneda aquí o allá sobre números, en lugar de plegarse al cálculo de probabilidades. Que la ciencia retrasaba su carrera contándose una y otra vez las piernas y que hacer novillos nos pone en el buen camino. Que se habían visto jaurías perder la pista, mientras que el hocico de un chucho cualquiera daba en el clavo. En fin, mil delicadezas en las que busco excusas a mi ignorancia y el permiso para recomponer mi asiento. ${ }^{52}$

En Poincaré, quien siempre sostuvo que la sensibilidad y la intuición eran imprescindibles para la invención matemática, encontró Cocteau una voz autorizada en la que apoyarse para defender el valor de la intuición poética frente al positivismo científico. En el otro extremo de este mismo volumen volvería el artista a invocar el espíritu del matemático para señalar hasta qué punto los científicos temían derribar algunos dogmas y caer en la fantasía y en lo poético: «Es probablemente lo que uno de ellos (Henri Poincaré) dejaba entender al decirme, durante mi juventud, en casa de Mme. Raoul Duval, que algunos temas de experiencia eran el lugar de fenómenos demasiado particulares para que pudieran prestar algún servicio y autorizasen a sacar de ellos algún provecho. Añadía que los poetas tenían "mucha suerte", pero que no se les creía, a falta de pruebas» ${ }^{53}$. Cocteau sabía por propia experiencia que la poesía tenía su propia matemática, que existía en la escritura algo que «entrecruzaba líneas, triángulos rectángulos, hipotenusas, diámetros. Algo que sumaba, multiplicaba, dividía. Algo que aprovechaba mis recuerdos íntimos para humanizar su álgebra» ${ }^{54}$. Poeta que compartía con Poincaré una misma concepción visual de la realidad, Cocteau reivindicaba la libertad de «no seguir los raíles de la ciencia», ya que «se puede tener en estima a la Escuela Politécnica y poner en duda las cifras. ¿Dos y dos son cuatro? Lo dudo mucho, si sumo dos lámparas y dos sillones» ${ }^{55}$. Para el artista no se trataba de rechazar los logros de la ciencia sino de considerarlos en su justa medida devolviendo a la vez a la poesía el aspecto que había perdido. Y en este juego anamórfico las ideas de Poincaré resultaban indispensables desde el punto de vista de Cocteau.

\footnotetext{
${ }^{50}$ Jean Cocteau, Le secret professionnel, en Poésie critique I. Paris, Gallimard, 1959, p. 48.

${ }^{51}$ Jacques Brosse, Cocteau. Paris, Gallimard, 1970, p. 44.

52 Jean Cocteau, Journal d'un inconnu. Paris, Bernard Grasset, 1953, p. 11.

${ }^{53}$ Ibíd., p. 182.

${ }^{54}$ Ibíd., p. 51.

${ }^{55}$ Ibíd., pp. 189-190.
} 
Tan solo unas páginas antes de evocar su encuentro con Poincaré en casa de Mme. Raoul Duval, Cocteau sostenía en el Diario de un desconocido que «el tiempo era un fenómeno de perspectiva análogo al de la calavera de Holbein» ${ }^{56}$. El perspectivismo temporal de Proust, la teoría de la Relatividad de Einstein y sobre todo la filosofía matemática de Poincaré — quien ya había concebido un espacio de cuatro dimensiones al incluir el tiempo como una de ellas- confluyen en esta frase después de haber sido todos ellos comentados en el mismo capítulo. Ahora bien, esta fugaz alusión a la anamorfosis terminará cuajando en el pensamiento de Cocteau hasta convertirse en una imagen metafórica de la propia poesía.

En efecto, unos años más tarde, en abril de 1961, el escritor publicaría en la revista Le Monde et la Vie un artículo titulado «Notas alrededor de una anamorfosis. Un fenómeno de reflexión» destinado a los jóvenes científicos, tal como se decía en la portada. Aquí aparecía en primer plano una foto del venerable poeta, a la edad de cincuenta y dos años, mirando fijamente a sus lectores, con una mano descansando sobre un cartón anamórfico cuya imagen original era restituida en un espejo cilíndrico. Como él mismo explicaba en el interior de la revista, se trataba de un regalo que le habían hecho por Navidad y que le había dejado bastante desconcertado:

\begin{abstract}
Sobre un cartón análogo al del juego de la oca, parece que algún descuido haya tirado un cuenco de salsa blanca. De ello resulta un desorden fotográfico de manchas y de líneas que proclamarían abstractas el triunfo oficial del arte revolucionario, su paso de izquierda a derecha, y viejas investigaciones que arrancan con Paolo Ucello (según Marcel Schwob) y reaparecen hacia 1913 con El Transiberiano o La Pequeña Jeanne de France de Blaise Cendrars, acompañado en el margen, por la Señora Delaunay-Terk, con una larga tira de formas multicolores. ${ }^{57}$
\end{abstract}

Con esta frase de composición tan elíptica como enmaranada, Cocteau vincula de entrada el objeto anamórfico con la tradición de la pintura abstracta: desde Paolo Ucello, tal como lo retrata Schwob en sus Vidas imaginarias, es decir empeñado en representar el universo como se refleja en el ojo de Dios, observando cada cosa desde la multiplicidad de sus ángulos, y cuya obra maestra desconocida acabaría constituyendo para los demás un revoltijo de líneas, hasta el poema-cuadro simultaneista de Cendrars y Sonia Delaunay, de dos metros de longitud una vez desplegado, a imagen del mundo que, en palabras del poeta, «se estira, se alarga y se retira como un acordeón al que una mano sádica atormenta» ${ }^{58}$ y que encuentra su exacto reflejo a su lado, en las formas geométricas iridiscentes del cubismo órfico de la pintora. En realidad, la imagen caótica que le habían regalado a Cocteau era una reproducción del cuadro anamórfico realizado por Domenico Piola en pleno siglo XVII inspirándose en el famoso retablo de La Erección de la Cruz (1610) de Rubens. Una vez enderezada la imagen en el espejo cilíndrico colocado en su centro aparecía la figura de Cristo en el momento de ser alzado en la cruz, en una composición ya de por sí marcadamente diagonal y barroca. El extraño objeto era, pues, susceptible de despertar el interés de un espíritu inquieto y curioso como el de Cocteau. Lo que para cualquier otro

\footnotetext{
${ }^{56}$ Ibíd., p. 176.

57 Jean Cocteau, «Notes autour d'une anamorphose. Un phénomène de réflexion», Cahiers Jean Cocteau, 9 (1981), pp. 245-257 (Le monde et la vie, avril 1961). El resto de las citas de Cocteau proceden de este mismo artículo.

${ }^{58}$ Blaise Cendrars, Du monde entier. Poésies complètes 1912-1924. Paris, Gallimard, 1967, p. 34.
} 
habría supuesto una simple diversión de cinco minutos, entre sus manos iba a convertirse, como reza la portada de la revista, en «un puente entre la poesía y la ciencia».

La anamorfosis es, en efecto, un «fenómeno de reflexión» para Cocteau, es decir el reflejo deformado de otra imagen original pero también un motivo para la reflexión, un estímulo capaz de despertar en él un auténtico torbellino de ideas. Como él mismo explicaba, en su caso este fenómeno se convirtió en «una puerta del castillo de Barbazul detrás de la cual se encuentran» algunas certezas muertas y pasillos laberínticos que «me condujeron a una tierra de nadie donde se encuentran la poesía y la ciencia». Para el poeta no era cuestión de dedicarse al estudio de la ciencia sino de concebir «la poesía como una ciencia exacta — si es que puede existir una». Y es que Cocteau realiza en sus obras «cálculos con los cuales controlo y preservo las casualidades que dan testimonio de un yo oscuro del que no soy más que la obediente mano de obra». Intuición, inspiración, instinto, invención, términos todos desacreditados por la ciencia, con la excepción de algunos sabios como Poincaré.

El arte, sostiene Cocteau en estas mismas «Notas alrededor de una anamorfosis», solo aventaja a la ciencia porque cada obra brota repentinamente sin por ello anular al resto de la obras, «mientras que la ciencia debe seguir un largo camino y, según la divertida frase de Henri Poincaré, "contar una y otra vez sus patas", lo cual frena su paso». Pero algo estaba cambiando y el poeta francés había visto con sorpresa como algunos jóvenes científicos no dudaban en tratarle de igual a igual con la esperanza de descubrir en su escuela en libertad «el tubo apto para cambiar en fórmula las manchas secretas de la anamorfosis universal». Y como no le parecía que tuviera nada especial que aportar a estos jóvenes que por fortuna no se burlaban del poder milagroso de los poetas, Cocteau no podía más que pasarles a su vez el testigo que él mismo había recibido en su juventud de la mano de Poincaré transmitiéndoles una de sus sentencias: «dejadme citaros otra hermosa frase de Henri Poincaré. La pronunció en mi presencia, cuando yo era muy joven, pues mi curiosidad le interpelaba, seducida ya por las exploraciones peligrosas de la mente. "Por lo que se refiere a las relaciones de la ciencia moderna con lo desconocido, le diré que empezamos a oír los primeros picotazos de los mineros que vienen a nuestro encuentro"». Ingeniero de minas como Novalis, Henri Poincaré no ignoraba que el auténtico científico, al igual que el poeta, es un minero que alumbra con su humilde lámpara la bóveda celeste.

En la anamorfosis de Domenico Piola descubre Cocteau una metáfora del poder revelador de la poesía. La poesía es para este «una pasarela significativa construida entre el universo conocido y el desconocido», un lenguaje más allá de las lenguas que trasciende las fronteras genéricas de las artes y revela lo invisible. En su época, concluía Cocteau estas «Notas alrededor de una anamorfosis», solo como fuente petrificante podía la poesía ocupar un lugar en la sociedad «al poseer la tinta del poeta la propiedad singular de petrificar el vacío, de cambiar lo abstracto en objeto, de precipitar noche en plena luz, en fin, de poner el tubo sobre la anamorfosis (o para expresarme coloquialmente), de soplarnos noticias por un tubo sobre lo desconocido». Ese juego de palabras trascendente que es la poesía difiere sin embargo sustancialmente de un juguete anamórfico en un aspecto crucial. El lector no suele tener, en efecto, entre sus manos el tubo necesario para enderezar el sentido de las palabras. 
Estas mismas «Notas alrededor de una anamorfosis» distan mucho de ser de fácil lectura, ya que, además de estar plagadas de brumosas alusiones a escritores, pensadores, científicos y obras artísticas, las ideas de Cocteau aparecen diseminadas por sus páginas en un orden que a simple vista parece caótico. El artículo mismo es una anamorfosis, y así lo confiesa el propio poeta al adivinar el pensamiento de sus lectores: «Vale, me dirá el lector, pero yo necesitaría también un tubo revelador para traducir la anamorfosis de sus notas». Pues bien, aclara el poeta, ante estas páginas solo queda «volver a empezar el recorrido del juego de la oca», regresar al punto de partida para leerlo todo de nuevo con otra perspectiva, reflexionando sobre este «fenómeno de reflexión» que es el texto. A veces uno tendrá que detenerse en una casilla oscura, pero otras veces caerá en un lugar que permitirá cruzar de un salto a otra dimensión. Una simple alu sión encerrará todo un complejo juego de referencias. Así, por ejemplo, al detenernos en la figura de Sonia Delaunay evocada por Cocteau averiguaremos que esta pintora visitaba a menudo el taller de los hermanos Duchamp donde los cubistas comentaban las teorías de Poincaré; aprenderemos asimismo que Blaise Cendrars, coautor de La Prosa del Transiberiano, que Cocteau había emparentado con la anamorfosis de Piola, era también un gran admirador de Henri Poincaré a quien citaba por ejemplo en El hombre fulminado, «casualmente», a propósito del inútil cálculo de probabilidades frente al azar... 59

Y entonces, de repente, comprenderemos que en el centro mismo de la maraña verbal de Cocteau el azar extrae un sistema de la sombra, repararemos en las reflexiones de Poincaré alzándose en toda su autoridad en medio de este discurso caótico. Unas palabras - dejándonos llevar por la corrienteque convertirán al eminente matemático en el necesario tubo corrector en cuyo reflejo se adivina la silueta de un puente que, a pesar de verse hoy amenazado por una montaña cursi de candados, sigue comunicando en París las orillas del arte y de la ciencia.

\footnotetext{
59 «[...] la suerte, la suerte que Henri Poincaré ha tratado en vano de captar en una fórmula matemática tal como saben todos los jugadores que han buscado fortuna en el tapete verde contando con esta fórmula que se encuentra en las Obras Completas del eminente matemático» (Blaise Cendrars, L’homme foudroyé. Paris, Denoël, 1945, p. 60).
} 